\title{
Modelling CAR Export from Slovakia to the United Kingdom - Vector Error Correction Approach
}

\section{Renáta Pitoňáková ${ }^{1}$}

\begin{abstract}
The aim of the article is to identify determinants of export of road vehicles from Slovakia to the United Kingdom. The Error correction model is based on monthly data from January 2008 to November 2018. The modelling identifies short and long-run effects of real effective exchange rate, inflation rate and industrial production on foreign demand of transport equipment. The real effective exchange rate indicates competitiveness of domestic producers towards most important trade partners, inflation rate of Slovakia is a proxy for macroeconomic environment and industrial production of the UK stands in for the income variable. The results suggest that export of road vehicles is in the long-run impacted by exchange rate and industrial production. The appreciation of exchange rate reduces export from SR to the UK while rising income increases foreign demand. In the short-run trading with motor vehicles is impacted by all three explanatory variables. The Error correction term indicates that roughly $30 \%$ of disequilibrium in the previous month will be corrected in the current month. The implications are for governing bodies to manage the current commodity framework which is at present mainly oriented on machinery and transport equipment and to support companies from other industries aiming to create more diversified export commodity structure.
\end{abstract}

Keywords: Export, Road Vehicles, Cointegration, VECM model

JEL Classification: C01, C3, F1, F14

Received: 2 June 2019 / Accepted: 23 August 2019/Sent for Publication: 5 December 2019

\section{Introduction}

The car production ranks Slovakia among world leaders. Nearly 200 cars per 1000 inhabitants were manufactured in 2018. There are four car factories on the territory of Slovakia: Volkswagen Slovakia in Bratislava (since 1991), PSA Peugeot Citroën Slovakia in Trnava (since 2003), Kia Motors Slovakia in Žilina (since 2004) and Jaguar Land Rover in Nitra (since 2018). Slovakia is small and open economy; the share of export to GDP achieved $101.5 \%$ in 2017 showing a great importance of foreign demand for economic activity. The UK is Slovakia's eighth largest export market with two

\footnotetext{
${ }^{1}$ Comenius University in Bratislava, Faculty of Social and Economic Sciences, Mlynské luhy 4, 82105 Bratislava, Slovakia, renata.pitonakova@fses.uniba.sk
}

(C) 2019 by the authors; licensee Review of Economic Perspectives / Národohospodářský obzor, Masaryk University, Faculty of Economics and Administration, Brno, Czech Republic. This article is an open access article distributed under the terms and conditions of the Creative Commons Attribution 3.0 license, Attribution - Non Commercial - No Derivatives. 
dominating items: cars and screens, together accounting of nearly $60 \%$ of the total (Beblavý and Bilč́k, 2016). The share of the UK on the total Slovakia exports is about $6 \%$. In 2015 the share of road vehicles on total export from Slovakia to the UK achieved $48 \%$ (with Germany, the main trading partner of Slovakia it was $34 \%$ ) $47 \%$ in 2016 (with Germany $32 \%$ ) and in 2018 it was $43 \%$ (with Germany $40 \%$ ). The UniCredit Bank (12/2019) states that the markets of the EU and the USA covering about $19 \%$ of the total world sell of new cars appeared stagnating in 2017. Almost every third car in the world was sold in China in 2017 but in 2018, the car selling on the biggest world market with new cars (China) dropped down by about $4 \%$ compared to the previous year. Due to a severe competition in the car industry and continual changes in demand for cars on both the EU and Extra-EU market it is of importance to put attention on factors impacting the sale of transport equipment within selected economies. The attempt of this paper is to identify and quantify factors determining the export of transport equipment (road vehicles) from Slovakia into the United Kingdom. The analysis is important, because the share of exported cars on total export of Slovakia to the UK exceeds the export of road vehicles to Germany which is the main trading partner for Slovakia. The article is structured as follows. After the introductory part there is an overview of corresponding literature, following part presents data and model, the fourth part offers results and discussion, the last part summarises.

\section{Literature Review}

Economic theory suggests explaining foreign demand by core factors such as income level of importing country, price level, and exchange rate. Price levels and real effective exchange rate are indicating competitiveness of exporting country/commodity. The standard set of fundamental variables is usually added by other variables which are specific for a given economy, sector or economic entity. Much attention is put on export performance of individual countries using distinct research methods. Different conclusions were derived in the literature depending on the applied econometric procedures. The majority of papers use cointegration and error correction modelling. Erdey and Pőstényi (2017) analysed determinants of exports of Hungary between 1993-2014, showing that economic size, common border, and free trade agreements had a statistically significant positive effect on exports. Gökmen and Turen (2013) focused on high technology export of EU-countries using panel cointegration approach. Their results suggest that economic freedom level, human development level and foreign direct investments aggregately had a positive impact on the high technology export. Havrlant and Hušek (2011) examined cost factors that influenced export of the Czech Republic, showing macroeconomic relations between export dynamics, development of foreign demand, domestic and foreign price levels. Sergi and Vít (2004) identified relation between export and savings in the Czech economy. Their study supports the paradigm which relates a country's increase in domestic savings to exports. Olczyk and Kordalska (2017) compared determinants of international competitiveness measured by the net exports of the manufacturing sectors in the Czech and Polish economies using the database of 13 manufacturing sub-sectors in 1995-2011. Results suggested a better capacity of the Czech economy to correct deviations from the equilibrium. Heinze (2018) inspected German export on and extra European Monetary Union (EMU) market. The outcomes suggest that for the German economy the real exchange rate was not the indi- 
cator for explaining German export success. Cieślik et al. (2015) focused on the analysis of export performance of Estonia, Latvia, Lithuania, the Czech Republic, Hungary, Poland, and Slovakia. Estimation results obtained for the Baltic and Central European Countries (CECs) indicated that the probability of exporting was positively related to the level of productivity, firm size, and the share of university graduates in productive employment and the internationalization of firms. Sertić, Vučković and Perić (2015) provided analysis on the determinants of export performance on the extensive data-set of the 27 European Union member states' total manufacturing and high tech manufacturing industry. The results indicated importance of stable macroeconomic environment for boosting production capacity and domestic demand essential for better export performance and the competitiveness of the manufacturing industry. Naghshpour and Sergi (2010) analysed exports and economic growth of East European Economies within 1996-2007 indicating that positive net effect of increased exports and imports results in increased production defined as growth. Haluška and Dolinič (2018) dealt with macroeconomic performance of the Slovak economy in the years 1995-2017, examining domestic and foreign demand. Beblavý and Bilčík (2016) focused on Slovakia and Brexit analysing the free movement of goods, labour, services, and capital. They assert that financial services are nearly irrelevant to the Slovak position on Brexit, as the whole Slovak banking sector is foreign owned - primarily by Italian (Intesa and Unicredit) and Austrian (Raiffeisen and Erste) banks. Ključnikov and Popesko (2017) point out that Slovak entrepreneurs primarily supplied their products and services on the domestic market, while their export potential is limited. In addition, the assessment of the state support of export activities seemed to be rather negative. Cetin and Ackrill (2018) examined all six possible causal relationships between Slovakia's exports, imports, and growth finding evidence for supporting both the export-led-growth hypothesis and the import-led-growth hypothesis. Szkorupová (2014) inspected the relation between foreign direct investment, economic growth and export in Slovakia revealing a positive impact of foreign direct investment and positive impact of export on gross domestic product. Pitoňáková (2019 a, b) focused on export of goods from Slovakia on the extra EU market. The findings indicate that Machinery and transport equipment section has a high level of competitiveness. Fitzová and Žídek (2015) examined the relationship between trade and economic growth in the Czech and Slovak Republics stressing the importance of exports for the economic growth in both countries.

There are various studies addressing determinants of car exports. Rentala, Anand and Shaban (2017) presented an empirical analysis of the Indian automobile industries. Profitability was found to be important in the Indian automobile industry. Resiandini (2014) compared data on Japanese and Korean automobile exports to the USA to examine consistency with the Alchian-Allen theorem. Melwani and Sitlani (2017) analysed export performance and trends of automobile industry in India. The forecast trend values showed that the exports in personal vehicles, commercial vehicles, two-wheelers and three-wheelers would increase in India in future. Karlsson, Melin and Cullinane (2018) applied a gravity model to identify the impact of potential Brexit scenarios on German car exports to the UK. All tested Brexit scenarios were found to negatively impact passenger cars export volumes from Germany to the UK. The level of tariffs was found to have the most significant effect. Dalton and Goksel (2013) analysed the Japanese car exports to the United States showing that learning and reputation influence the Japanese car import. 


\section{Data and Model}

This section of the paper presents data and model used for identification and quantification of factors affecting export performance of Slovakia in car industry.

\section{Data}

The time span of observation covers monthly data starting on January 2008 ending November 2018. Data were obtained from the database of the central bank of the Slovak Republic (NBS), Statistical Office of the Slovak Republic, Statistical office of the EU (Eurostat) and Comext (Eurostat's reference database for statistics on international trade in goods). The following variables were used in modelling: export of road vehicles from Slovakia to the UK (XRV), exchange rate (REER), growth of industrial production of the UK (IUK) and inflation in the Slovak Republic (SR) (INFSK) ${ }^{2}$. Figure 1 presents the path of variables under consideration. Table 1 describes variables of the model and expected signs.

Figure 1. Development of Export (XRV), Exchange rate (REER), Industrial production (IUK), Inflation (INFSK)

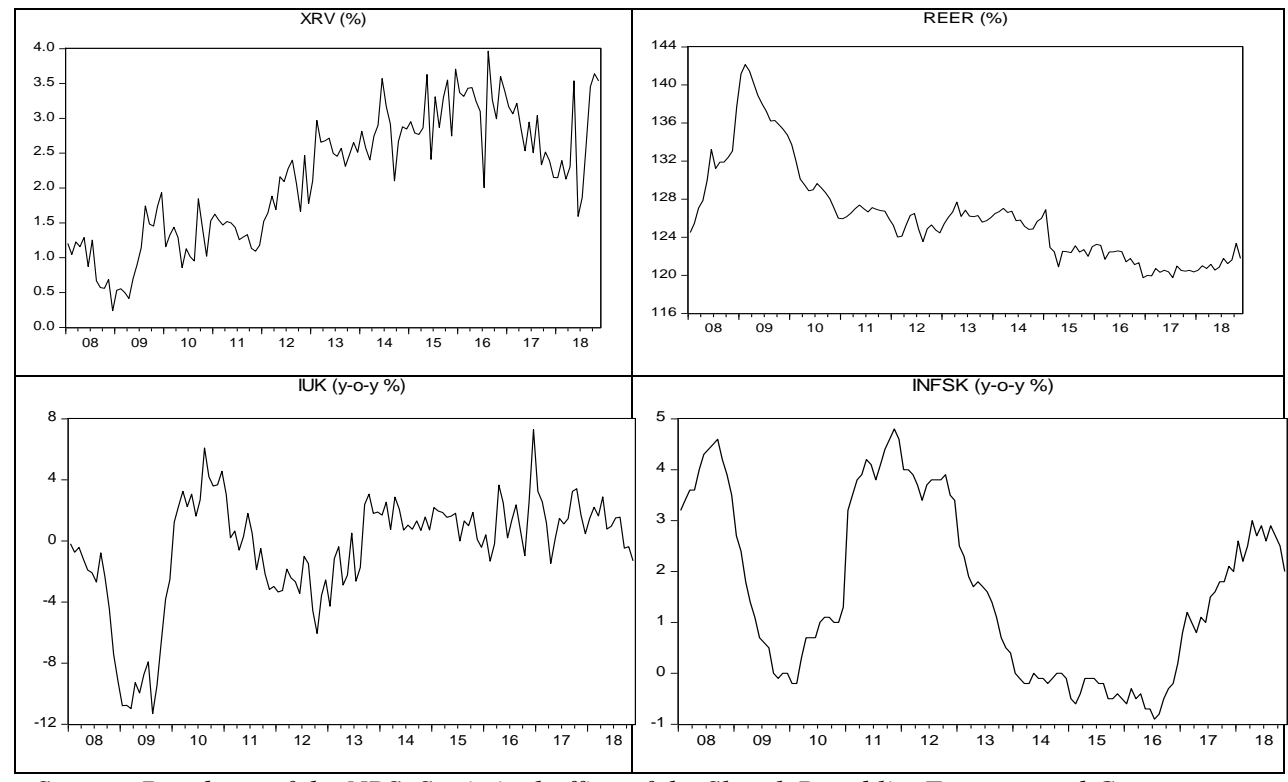

Source: Database of the NBS, Statistical office of the Slovak Republic, Eurostat and Comext

Rising prices and appreciation in the exchange rate are expected to decline demand for foreign production as goods are becoming more expensive, and competitiveness is de-

\footnotetext{
${ }^{2}$ Business confidence index for the UK, Consumer confidence index for the UK and import indicators were used but were not statistically significant.
} 
clining. If income increases, demand is expected to increase because favourable economic activity is associated with higher employment.

Table 1. Description of variables and expected signs of parameters

\begin{tabular}{|c|l|c|}
\hline Variable & \multicolumn{1}{|c|}{ Description } & Expected sign \\
\hline XRV & $\begin{array}{l}\text { Share of export of road vehicles from Slovakia to the UK on total export } \\
\text { of Slovakia to the UK (seasonally adjusted by Census X11) }\end{array}$ & \\
\hline REER & $\begin{array}{l}\text { The real effective exchange rate for Slovak economy (REER_PPI- } \\
\text { manufacturing, seasonally adjusted by Census X11) }\end{array}$ & - \\
\hline IUK & $\begin{array}{l}\text { Industrial production } 3 \text { in the UK - a proxy for GDP ( Percentage change } \\
\text { compared to same period in previous year) }\end{array}$ & + \\
\hline INFSK & Inflation in SR: HICP (annual rate of change) & - \\
\hline
\end{tabular}

Higher employment and higher income enable consumers to higher spending.

\section{Model}

Most economic variables are not stationary and if there is evidence for nonstationarity, then testing for a common nonstationary component by means of a cointegration test is required (Kleiber and Zeileis, 2008). The order of integration of a time series is of great importance for analysis, therefore several statistical tests have been developed for investigating it (Lütkepohl and Krätzig, 2004). The initial analysis in this paper began with determining the order of integration of variables under review: export (XRV), exchange rate (REER), industrial production (IUK) and inflation (INFSK) using the ADF unit root test of Dickey-Fuller (Dickey and Fuller, 1979). Table 2 shows the results of ADF unit root test in level and first difference.

Table 2. Results from ADF unit root test

\begin{tabular}{|c|c|c|c|c|}
\hline \multirow{2}{*}{ Variable } & \multicolumn{3}{|c|}{ LDF statistic } \\
\cline { 2 - 5 } & \multicolumn{2}{|c|}{ Level } & \multicolumn{2}{c|}{ First Difference } \\
\hline \multirow{2}{*}{ Intercept } & Trend and Intercept & Intercept & Trend and Intercept \\
\hline XRV & -1.491 & -2.104 & $-13.116^{* * *}$ & $-13.063^{\text {** }}$ \\
\hline REER & -1.022 & -3.183 & $-8.971^{* * *}$ & $-8.972^{\text {*** }}$ \\
\hline IUK & -2.663 & -3.062 & $-10.402^{* * *}$ & $-10.360^{\text {** }}$ \\
\hline INFSK & -2.117 & -2.034 & $-5.198^{* * *}$ & $-5.217^{\text {***}}$ \\
\hline
\end{tabular}

Notes: Outcomes from EViews 10, ***,*** imply significance at $1 \%, 5 \%, 10 \%$ levels respectively

\footnotetext{
${ }^{3}$ Involving mining and quarrying; manufacturing; electricity, gas, steam and air conditioning supply.
} 
The test has the hypothesis of nonstationarity as the null with the alternative being that the series is stationary. The maximum lags were set according to the Schwarz information criterion (automatic selection). The outcomes indicate that all variables applied in this analysis are nonstationary in their levels, but they are stationary in their first difference. The series are I (1). As Lütkepohl and Krätzig (2004) point out, the vector error correction model (VECM) is a suitable modelling framework if variables are I(1). Specifying the VECMs requires setting appropriate lag order ${ }^{4}$ and testing for the cointegrated rank. Table 3 displays the results.

Table 3. Results from testing cointegrated rank

\begin{tabular}{|c|c|c|c|c|c|}
\hline \multicolumn{5}{|c|}{ Cointegration test } \\
\hline Eigenvalue & H0: rank & Trace & $\begin{array}{c}95 \% \text { Critical } \\
\text { value }\end{array}$ & $\begin{array}{c}\text { Maximum } \\
\text { eigenvalue }\end{array}$ & $95 \%$ Critical value \\
\hline 0.251 & $=0$ & $59.925^{\star}$ & 47.856 & $35.228^{*}$ & 27.584 \\
\hline 0.113 & $\leq 1$ & 24.697 & 29.797 & 14.583 & 21.132 \\
\hline 0.058 & $\leq 2$ & 10.114 & 15.494 & 7.317 & 14.265 \\
\hline 0.023 & $\leq 3$ & 2.797 & 3.841 & 2.797 & 3.841 \\
\hline
\end{tabular}

Note: Critical values: Osterwald-Lenum (1992). Results from EViews 10

The Johansen procedure (Johansen 1988, 1991, 1995) was applied for testing a cointegrating rank. The results show that the Johansen test rejects rank 0 and does not reject rank 1, 2, and 3 for eight lags. There is one cointegrating relationship among XRV, REER, IUK, and INFSK at the 0.05 level. This suggests a long-run relationship among XRV, REER, IUK, and INFSK. Because cointegrated relations are present in a system of corresponding variables, it is useful to estimate the coefficients with the vector error correction model (VECM).

Our VECM has the following form:

$\Delta \mathrm{XRV}_{\mathrm{t}}=\alpha_{1}+\beta_{1}\left(\mathrm{ECT}_{\mathrm{t}-1}\right)+\sum_{\mathrm{j}=1}^{8} \gamma_{1 \mathrm{j}} \Delta \mathrm{XRV}_{\mathrm{t}-\mathrm{j}}+\sum_{\mathrm{j}=1}^{8} \delta_{1 \mathrm{j}} \Delta \mathrm{REER}_{t-j}+$

$\sum_{\mathrm{j}=1}^{8} \varepsilon_{1 \mathrm{j}} \Delta \mathrm{IUK}_{\mathrm{t}-\mathrm{j}}+\sum_{\mathrm{j}=1}^{8} \zeta_{1 \mathrm{j}} \Delta \mathrm{INFSK}_{\mathrm{t}-\mathrm{j}}+\mathrm{u}_{1 \mathrm{t}}$

$\Delta$ REER $_{\mathrm{t}}=\alpha_{2}+\beta_{2}\left(\mathrm{ECT}_{\mathrm{t}-1}\right)+\sum_{\mathrm{j}=1}^{8} \gamma_{2 \mathrm{j}} \Delta \mathrm{XRV}_{\mathrm{t}-\mathrm{j}}+\sum_{\mathrm{j}=1}^{8} \delta_{2 \mathrm{j}} \Delta \mathrm{REER}_{\mathrm{t}-\mathrm{j}}+$

$\sum_{\mathrm{j}=1}^{8} \varepsilon_{2 \mathrm{j}} \Delta \mathrm{IUK}_{\mathrm{t}-\mathrm{j}}+\sum_{\mathrm{j}=1}^{8} \zeta_{2 \mathrm{j}} \Delta \mathrm{INFSK}_{\mathrm{t}-\mathrm{j}}+\mathrm{u}_{2 \mathrm{t}}$

$\Delta \mathrm{IUK}_{\mathrm{t}}=\alpha_{3}+\beta_{3}\left(\mathrm{ECT}_{\mathrm{t}-1}\right)+\sum_{\mathrm{j}=1}^{8} \gamma_{3 \mathrm{j}} \Delta \mathrm{XRV}_{\mathrm{t}-\mathrm{j}}+\sum_{\mathrm{j}=1}^{8} \delta_{3 \mathrm{j}} \Delta \mathrm{REER}_{t-j}+$ $\sum_{\mathrm{j}=1}^{8} \varepsilon_{3 \mathrm{j}} \Delta \mathrm{IUK}_{\mathrm{t}-\mathrm{j}}+\sum_{\mathrm{j}=1}^{8} \zeta_{3 \mathrm{j}} \Delta I N F S K_{t-j}+\mathrm{u}_{3 \mathrm{t}}$

\footnotetext{
${ }^{4}$ The number of lags was set in VAR according to information criteria. According to the Akaike information criterion (AIC) eight lags should be appropriate.
} 
$\Delta \mathrm{INFSK}_{\mathrm{t}}=\alpha_{4}+\beta_{4}\left(\mathrm{ECT}_{\mathrm{t}-1}\right)+\sum_{\mathrm{j}=1}^{8} \gamma_{4 \mathrm{j}} \Delta \mathrm{XRV}_{\mathrm{t}-\mathrm{j}}+\sum_{\mathrm{j}=1}^{8} \delta_{4 \mathrm{j}} \Delta \mathrm{REER}_{t-j}+$ $\sum_{\mathrm{j}=1}^{8} \varepsilon_{4 \mathrm{j}} \Delta \mathrm{IUK}_{\mathrm{t}-\mathrm{j}}+\sum_{\mathrm{j}=1}^{8} \zeta_{4 \mathrm{j}} \Delta \mathrm{INFSK}_{\mathrm{t}-\mathrm{j}}+\mathrm{u}_{4 \mathrm{t}}$

where XRV, REER, IUK, INFSK are described in Table 1. $\Delta$ is a first difference operator, ECTs are the error correction terms derived from long-run cointegrating relationship by means of the Johansen Maximum Likelihood Procedure (ML), $\beta_{1} \ldots, \beta_{4}$ are long-run parameters, $\gamma_{1 j} \ldots, \gamma_{4 j}, \delta_{1 j} \ldots, \delta_{4 j}, \varepsilon_{1 j} \ldots, \varepsilon_{4 j}, \zeta_{1 j} \ldots, \zeta_{4 j}$ are parameters of short run relantionship, $\mathrm{j}=1 \ldots, 8, \mathrm{u}_{\mathrm{it}}(\mathrm{i}=1,2,3,4)$ are the error terms.

\section{Results and discussion}

The cointegrating equation (5) shows a negative impact of REER on XRV but a positive influence from IUK and INFSK however, the inflation is not statistically significant. Since variables are in per cents, e.g. a rise of REER by one percentage point declines export by more than one percentage point (1.338). The export is stimulated by higher income in the UK.

$X R V=+207.526-1.338(\text { REER })^{* * *}+2.806(\text { IUK })^{* * *}+0.454($ INFSK $)$

Note: Estimates from EViews 10, derived by Johansen procedure. $* * *$ implies significance at $1 \%$ level.

Signs of coefficients for exchange rate and income are in compliance with the expectations presented in Table 1 apart of inflation which has a positive sign but is statistically non-significant. A note should be made to this outcome. The modelling in this paper is based on monthly disaggregated data taking into account export of road vehicles to the UK expressed as a share on total exporting from SR to the UK. Although theory suggests a negative relation, the negative sign of the coefficient can be assumed when using aggregated data for total exporting rather than structured data set. Furthermore the nature of macroeconomic environment in SR was changing within the observed period of time (2008 - 2018) from inflation to deflation within 2014 - 2016 and since 2017 price level returned back to inflation conditions. This non-stability may help explaining why inflation was revealed as non-significant. The results from the $\mathrm{VECM}^{5}$ are presented in Table 4 indicating the values of constant, error correction term parameters (ECT), coefficients of determination, adjusted coefficients of determination and F-Statistic. The ECT should be negative and significant indicating the speed of convergence to equilibrium. The ECT at the export variable is negative and statistically significant at 1 percent level. This outcome indicates that the error correction mechanism works properly. In the short-run export of road vehicles to the UK is adjusted by approximately 30 percent of the past month's deviation from equilibrium. The parameter of the ECT at the real effective exchange rate is negative but statistically not significant, while the parameter at the industrial production is positive and statistically significant. The parameter of the ECT at inflation is statistically significant and negative indicating a stability of the system.

\footnotetext{
${ }^{5}$ Additional results from the estimations of the VECM model are presented in Appendix.
} 
Table 4. Outcomes from VECM

\begin{tabular}{|c|c|c|c|c|}
\hline & $\Delta(\mathrm{XRV})$ & $\Delta$ (REER) & $\Delta(\mathrm{IUK})$ & $\Delta$ (INFSK) \\
\hline Constant & -0.128 & -0.099 & -0.023 & -0.043 \\
& {$[-0.273]$} & {$[-1.139]$} & {$[-0.169]$} & {$[-1.630]$} \\
\hline ECT(-1) & $-0.297^{* *}$ & -0.010 & $0.082^{* * *}$ & $-0.015^{\star * *}$ \\
& {$[-2.911]$} & {$[-0.538]$} & {$[2.807]$} & {$[-2.629]$} \\
\hline $\mathrm{R}^{2}$ & 0.557 & 0.405 & 0.531 & 0.517 \\
\hline Adj. $\mathrm{R}^{2}$ & 0.391 & 0.182 & 0.355 & 0.336 \\
\hline F-Statistic & 3.351 & 1.814 & 3.019 & 2.856 \\
\hline
\end{tabular}

Notes: Outcomes from EViews 10, *** implies significance at 1\%, t-statistics in parentheses

The speed of adjustment into the equilibrium is slow because about 1.5 percent of disequilibrium in the previous month will be corrected in the current month.

\section{Granger causality}

In order to test for short - term causality, the Granger causality testing was used. The test requires checking whether specific coefficients are zero (Lütkepohl and Krätzig, 2004). There are standard tests for zero restrictions on VAR coefficients: the $\chi^{2}$ or Ftests based on Wald principle.

Table 5 shows the results from the short-run causal relationship among XRV, REER, IUK and INFSK in equations (1), (2), (3) and (4) in the VECM which was tested by $\chi^{2}$ statistics showing the significance of the lagged variables in each of the four equations.

Table 5. Results from Granger causality test

\begin{tabular}{|c|c|c|c|c|c|c|c|c|c|c|c|c|}
\hline \multicolumn{10}{|c|}{$\Delta$ Dependent variable } \\
\hline & \multicolumn{3}{|c|}{$\Delta$ (RRV) } & \multicolumn{3}{c|}{$\Delta$ (RER) } & \multicolumn{3}{c|}{$\Delta$ (IUK) } & \multicolumn{3}{c|}{$\Delta$ (INFSK) } \\
\hline Excluded & $X^{2}$ & df & Prob. & $X^{2}$ & df & Prob. & $X^{2}$ & df & Prob. & $X^{2}$ & df & Prob. \\
\hline$\Delta$ (REER) & 17.18 & 8 & $\mathbf{0 . 0 3}$ & & & & 9.48 & 8 & 0.30 & 8.76 & 8 & 0.36 \\
\hline$\Delta($ IUK) & 37.87 & 8 & $\mathbf{0 . 0 0}$ & 7.41 & 8 & 0.49 & & & & 14.42 & 8 & 0.07 \\
\hline$\Delta$ (INFSK) & 30.65 & 8 & $\mathbf{0 . 0 0}$ & 12.94 & 8 & 0.11 & 7.87 & 8 & 0.45 & & & \\
\hline$\Delta$ (XRV) & & & & 9.44 & 8 & 0.31 & 20.78 & 8 & $\mathbf{0 . 0 1}$ & 18.21 & 8 & $\mathbf{0 . 0 2}$ \\
\hline
\end{tabular}

Notes: Outcomes from EViews 10. Values in bold indicate Granger causality among variables (5 \% level)

Equation (1) tests the Granger causality from REER (Real effective exchange rate), IUK (Industrial production) and INFSK (Inflation) on XRV (Export of road vehicles), equation (2) tests the Granger causality from XRV, IUK and INFSK on REER, equation (3) tests the Granger causality from XRV, REER, and INFSK on IUK and finally equation (4) refers to the impact of XRV, REER and IUK on INFSK. The results suggest that real exchange rate, income and inflation Granger cause export of road vehicles in the shortrun. These findings contradict to our outcomes from long-run relationship among export, real effective exchange rate, income and inflation because in the long-run inflation appeared statistically not significant. The results suggest a bi-directional causality running from export to income in the UK and a bi-directional Granger causality between export and inflation. The outcomes imply for governing bodies (Ministry of Economy, Minis- 
try of Foreign and European Affairs) to supervise the export performance balance and for monetary authorities to manage price level within the price stability goal.

The following diagnostics tests were performed on the model expressed by (1) - (4): the serial correlation Lagrange multiplier (LM) test (BG test) (Breusch, 1978; Godfrey, 1978); the heteroskedasticity test (BP test) (Breusch and Pagan, 1979); and the normality test (JB) (Jarque and Bera, 1980). The BG (8)-test has a p-value of $8.8 \%$. The null of non-autocorrelation is not rejected against the alternative of eight-order autocorrelation at the $5 \%$ level. The p-value of the BP test is $84.95 \%$, the null hypothesis of homoskedasticity is not rejected. The p-value of JB test is $83.9 \%$, the null hypothesis is not rejected - the residuals are normally distributed.

Stability of coefficients was tested by CUSUM test and CUSUM of Squares test. The plots are deployed at Figure 2.

\section{Figure 2. Results from CUSUM and CUSUM of Squares tests}

\section{CUSUM}

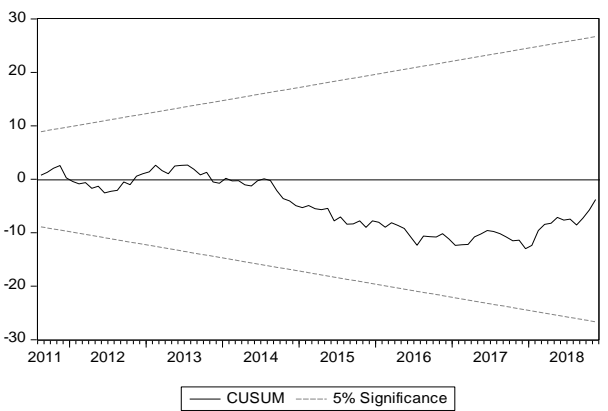

CUSUM of Squares

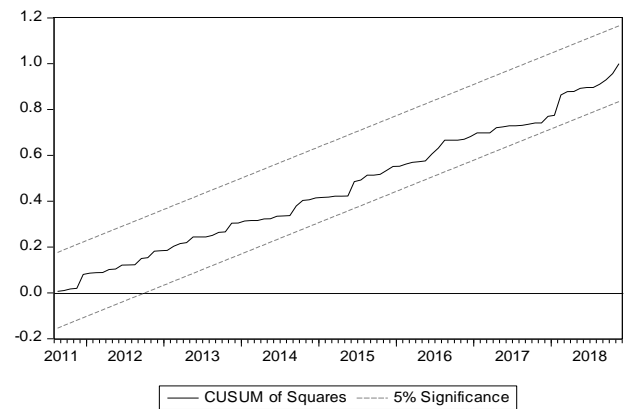

Note: Outcomes from EViews 10

The graph of the CUSUM statistics revolves around zero within its confidence bounds so the null hypothesis of parameter stability is not rejected. The graph of the CUSUM of Squares statistics does not hit the $5 \%$ significance bound. The results show that parameters are stable over the period of observation.

\section{Conclusion}

The article focused on investigation of determinants of exporting road vehicles from Slovakia to the UK. The findings suggest that in the long-run real effective exchange rate and income have a significant impact on export, while inflation appeared to be statistically not significant. In the short-run there is a bi-directional causality running from export to income in the UK and a bi-directional Granger causality between export and inflation. The findings identified the price level as a significant factor impacting exporting in the short-run. Results outline possible consequences when demand for automobile industry falls down because reduced foreign demand negatively hits economic activity, investment of companies, consumption of households and total em- 
ployment. It requires making changes in existing selling portfolio involving more commodities of traditional origin. These additional products could at least partially compensate for a reduced demand coming from the UK.

Disclosure statement: The author reported no potential conflict of interest.

\section{References}

BEBLAVÝ, M. \& BILČÍK, V. (2016). Slovakia and Brexit: A gentle approach to tough love, In: What To Do With the UK? EU perspectives on Brexit, Edited by Charles Wyplosz, CEPR Press, October 2016.

BREUSCH, S. T. (1978). Testing for Autocorrelation in Dynamic Linear Models, Australian Economic Papers, 17 (31), pp. 334-355.

BREUSCH, T. S. \& PAGAN, A. R. (1979). A Simple Test for Heteroscedasticity and Random Coefficient Variation, Econometrica, 47 (5), pp. 1287-1294. DOI: $\underline{10.2307 / 1911963}$

CETIN, R. \& ACKRILL, R. (2018). Exports, imports, growth and causality: a study of Slovakia, Post-Communist Economies, 30 (3), pp. 395-404. DOI: $\underline{10.1080 / 14631377.2018 .1442038}$

CIEŚLIK, A., MICHALEK, A., MICHALEK, J. \& MYCIELSKI, J. (2015). Determinants of Export Performance: Comparison of Central European and Baltic Firms, Czech Journal of Economics and Finance, 65 (3), pp. 211-229.

DALTON, J. T. \& GOKSEL, T. (2013). Reputation and Learning: Japanese Car Exports to the United States, Japan and the World Economy, 25, pp. 10-23. DOI: 10.1016/j.japwor.2013.01.004

DICKEY, D. A. \& FULLER, W. A. (1979). Distribution of the estimators for autoregressive time series with a unit root, Journal of the American Statistical Association, 74 (366), pp. 427-431.

ERDEY, L. \& PÖSTÉNYI, A. (2017). Determinants of Foreign Trade of Hungary: Trade Theory and the Gravity Model, Acta Oeconomica, 67 (1), pp. 77 - 97. DOI: $\underline{10.1556 / 032.2017 .67 .1 .5}$

FITZOVÁ, H. \& ŽÍDEK, L. (2015), Impact of Trade on Economic Growth in the Czech and Slovak Republics, Economics and Sociology, 8 (2), pp. 36-50. DOI: 10.14254/2071-789X.2015/8-2/4

GODFREY, L. G. (1978). Testing against General Autoregressive and Moving Average Error Models When the Regressors Include Lagged Dependent Variables, Econometrica, 46 (6), pp. 1293-1301. DOI: $\underline{10.2307 / 1913829}$

GÖKMEN, Y. \& TUREN, U. (2013). The Determinants of High Technology Exports Volume: A Panel Data Analysis of EU-15 Countries, International Journal of Management, Economics and Social Sciences, 2 (3), pp. 217 -232. 
HALUŠKA, J. \& DOLINIČ, J. (2018). Macroeconomic Performance of the Slovak Economy in the Years 1995-2017, Slovenská štatistika a demografia, 28 (3), pp. 57-76.

HAVRLANT, D. \& HUŠEK, R. (2011). Models of Factors Driving the Czech Export, Prague Economic Papers, 2011 (3), pp. 195-215.

HEINZE, H. (2018). The determinants of German exports: An analysis of intra- and extra-EMU trade, Working Paper, Institute for International Political Economy Berlin, No. 95/2018, Berlin School of Economics and Law, Institute for International Political Economy Berlin, Berlin.

JARQUE, C. M. \& BERA, A. K. (1980). Efficient test for normality, homoscedasticity and serial independence of regression residuals, Economic Letters, 6, pp. 255-259. DOI: $\underline{10.1016 / 0165-1765(80) 90024-5}$

JOHANSEN, S. (1988). Statistical Analysis of Cointegration Vectors, Journal of Economic Dynamics and Control, 12 (2-3), pp. 231-254. DOI: 10.1016/0165$\underline{1889(88) 90041-3}$

JOHANSEN, S. (1991). Estimation and Hypothesis Testing of Cointegration Vectors in Gaussian Vector Autoregressive Models, Econometrica, 59 (6), pp. 1551-1580. DOI: $\underline{10.2307 / 2938278}$

JOHANSEN, S. (1995). Likelihood-based Inference in Cointegrated Vector Autoregressive Models, Oxford University Press.

KARLSSON, J., MELIN, H. \& CULLINANE, K. (2018). The impact of potential Brexit scenarios on German car exports to the UK: an application of the gravity model, Journal of Shipping and Trade, 3 (12), pp. 2-22. DOI: 10.1186/s41072-018-0038-X

KLEIBER, CH. \& ZEILEIS, A. (2008). Applied Econometrics with R, Springer Science+BusinessMedia, LLC.

KLJUČNIKOV, A. \& POPESKO, B. (2017). Export and its Financing in the SME Segment. Case Study From Slovakia, Journal of Competitiveness, 9 (1), pp. 20 - 35. DOI: $10.7441 /$ joc.2017.01.02

LÜTKEPOHL, H. \& KRÄTZIG, M. (2004). Applied time series econometrics, Cambridge University Press, New York.

MELWANI, R. \& SITLANI, M. (2017). Export Performance and Trends of Automobile Industry in India, Prestige e-Journal of Management and Research, 4 (1), pp. 1-12.

NAGHSHPOUR S. \& SERGI B. S. (2010) Exports and Economic Growth of East European Economies, 1996-2007. In: Matoušek R. (eds) Money, Banking and Financial Markets in Central and Eastern Europe. Palgrave Macmillan Studies in Banking and Financial Institutions. Palgrave Macmillan, London

OLCZYK, M. \& KORDALSKA, A. (2017). Determinants of Net Exports in Polish and Czech Manufacturing: A Sectoral Approach with Error Correction Model, Conference paper: The 9th International Conference on Applied Economics, Contemporary Issues in Economy, At Nicolaus Copernicus University, Toruń, Poland. 
OSTERWALD-LENUM, M. (1992). A Note with Quantiles of the Asymptotic Distribution of the Maximum Likelihood Cointegration Rank Test Statistics, Oxford Bulletin of Economics and Statistics, 54 (3), pp. 461-471. DOI: 10.1111/j.14680084.1992.tb00013.x

PITOŇÁKOVÁ, R. (2019a). Investigation into the Slovak trade specialization, 6th International Conference on Education and Social Science, abstracts \& proceedings. ISBN 978-605-82433-5-4. - Istanbul : International Organization Center of Academic Research, 2019. - S. 1-1 [CD-ROM], Intcess 2019 [6] - Dubai, 04.02.2019 - 06.02.2019.

PITOŇÁKOVÁ, R. (2019 b). Comparative Advantages: Specialization on Extra EU Trade with Goods, SIBR 2019 Conference on interdisciplinary business \& economics research, Tokyo: Society of Interdisciplinary Business Research, 2019. ISSN 2223-5078.

RENTALA, S., ANAND, B. \& SHABAN, M. (2017). Determinants of export performance: An empirical analysis of the Indian pharmaceutical and automobile industries. In book: International Business Strategy, Edition: 1st Edition, Chapter: 11, Publisher: Palgrave Macmillan, 241-257.

RESIANDINI, P. (2014). Japanese and Korean automobile exports and the AlchianAllen theorem, International Journal of Trade and Global Markets, 7 (1), pp. 86 - 98. DOI: $10.1504 /$ IJTGM.2014.058725

SERGI, B. S. \& VÍT, K. (2004). How to Rationalize the Export-Saving Paradigm (the Czech experience), Prague Economic Papers, (2), pp. 115-120. DOI: 10.18267/j.pep.234

SERTIĆ, B. M., VUČKOVIĆ, V. \& PERIĆ, Š. B. (2015). Determinants of manufacturing industry exports in European Union member states: a panel data analysis, Economic Research-Ekonomska Istraživanja, $28 \quad$ (1), pp. 384-397. DOI: $\underline{10.1080 / 1331677 X .2015 .1043781}$

SZKORUPOVÁ, Z. (2014). A causal relationship between foreign direct investment, economic growth and export for Slovakia, Procedia Economics and Finance,15, pp. $123-128$.

Weekly notes, UniCredit Bank, 12/2019. 


\section{APPENDIX}

The outcomes from the estimations of the model equations

\begin{tabular}{|c|c|c|c|c|}
\hline Error Correction: & $\mathrm{D}(\mathrm{XRV})$ & $\mathrm{D}(\mathrm{REER})$ & $\mathrm{D}(\mathrm{IUK})$ & $\mathrm{D}$ (INFSK) \\
\hline CointEq1 & $\begin{array}{r}-0.297279 \\
(0.10213) \\
{[-2.91075]}\end{array}$ & $\begin{array}{r}-0.010247 \\
(0.01903) \\
{[-0.53851]}\end{array}$ & $\begin{array}{r}0.082110 \\
(0.02925) \\
{[2.80747]}\end{array}$ & $\begin{array}{r}-0.015064 \\
(0.00573) \\
{[-2.62890]}\end{array}$ \\
\hline $\mathrm{D}(\mathrm{XRV}(-1))$ & $\begin{array}{r}-0.383908 \\
(0.12718) \\
{[-3.01863]}\end{array}$ & $\begin{array}{r}0.002308 \\
(0.02369) \\
{[0.09740]}\end{array}$ & $\begin{array}{r}0.000187 \\
(0.03642) \\
{[0.00515]}\end{array}$ & $\begin{array}{r}0.012829 \\
(0.00714) \\
{[1.79794]}\end{array}$ \\
\hline $\mathrm{D}(\mathrm{XRV}(-2))$ & $\begin{array}{r}-0.209096 \\
(0.13666) \\
{[-1.53002]}\end{array}$ & $\begin{array}{r}-0.022734 \\
(0.02546) \\
{[-0.89290]}\end{array}$ & $\begin{array}{r}-0.080859 \\
(0.03914) \\
{[-2.06613]}\end{array}$ & $\begin{array}{r}0.005187 \\
(0.00767) \\
{[0.67644]}\end{array}$ \\
\hline $\mathrm{D}(\mathrm{XRV}(-3))$ & $\begin{array}{r}0.023371 \\
(0.14659) \\
{[0.15943]}\end{array}$ & $\begin{array}{r}-0.041304 \\
(0.02731) \\
{[-1.51236]}\end{array}$ & $\begin{array}{r}-0.002658 \\
(0.04198) \\
{[-0.06332]}\end{array}$ & $\begin{array}{r}0.016426 \\
(0.00822) \\
{[1.99721]}\end{array}$ \\
\hline $\mathrm{D}(\mathrm{XRV}(-4))$ & $\begin{array}{r}-0.104994 \\
(0.14673) \\
{[-0.71554]}\end{array}$ & $\begin{array}{r}-0.024145 \\
(0.02734) \\
{[-0.88320]}\end{array}$ & $\begin{array}{r}-0.049368 \\
(0.04202) \\
{[-1.17488]}\end{array}$ & $\begin{array}{r}0.020771 \\
(0.00823) \\
{[2.52300]}\end{array}$ \\
\hline $\mathrm{D}(\mathrm{XRV}(-5))$ & $\begin{array}{r}-0.107567 \\
(0.14876) \\
{[-0.72310]}\end{array}$ & $\begin{array}{r}0.020780 \\
(0.02771) \\
{[0.74977]}\end{array}$ & $\begin{array}{r}0.013140 \\
(0.04260) \\
{[0.30846]}\end{array}$ & $\begin{array}{r}0.030286 \\
(0.00835) \\
{[3.62873]}\end{array}$ \\
\hline $\mathrm{D}(\mathrm{XRV}(-6))$ & $\begin{array}{r}0.248991 \\
(0.14627) \\
{[1.70223]}\end{array}$ & $\begin{array}{r}-1.73 E-05 \\
(0.02725) \\
{[-0.00064]}\end{array}$ & $\begin{array}{r}-0.017513 \\
(0.04189) \\
{[-0.41810]}\end{array}$ & $\begin{array}{r}0.014200 \\
(0.00821) \\
{[1.73033]}\end{array}$ \\
\hline $\mathrm{D}(\mathrm{XRV}(-7))$ & $\begin{array}{r}0.297183 \\
(0.13118) \\
{[2.26543]}\end{array}$ & $\begin{array}{r}0.021006 \\
(0.02444) \\
{[0.85949]}\end{array}$ & $\begin{array}{r}-0.083236 \\
(0.03757) \\
{[-2.21572]}\end{array}$ & $\begin{array}{r}0.007751 \\
(0.00736) \\
{[1.05312]}\end{array}$ \\
\hline $\mathrm{D}(\mathrm{XRV}(-8))$ & $\begin{array}{c}0.240368 \\
(0.11701) \\
{[2.05416]}\end{array}$ & $\begin{array}{r}0.006382 \\
(0.02180) \\
{[0.29274]}\end{array}$ & $\begin{array}{r}-0.045073 \\
(0.03351) \\
{[-1.34510]}\end{array}$ & $\begin{array}{r}-0.005105 \\
(0.00657) \\
{[-0.77758]}\end{array}$ \\
\hline $\mathrm{D}(\operatorname{REER}(-1))$ & $\begin{array}{r}-0.715813 \\
(0.58316) \\
{[-1.22747]}\end{array}$ & $\begin{array}{r}0.114070 \\
(0.10865) \\
{[1.04991]}\end{array}$ & $\begin{array}{r}-0.447482 \\
(0.16700) \\
{[-2.67957]}\end{array}$ & $\begin{array}{r}-0.069529 \\
(0.03272) \\
{[-2.12506]}\end{array}$ \\
\hline $\mathrm{D}(\mathrm{REER}(-2))$ & $\begin{array}{r}-0.124504 \\
(0.60789)\end{array}$ & $\begin{array}{l}0.072552 \\
(0.11325)\end{array}$ & $\begin{array}{r}-0.044942 \\
(0.17408)\end{array}$ & $\begin{array}{r}-0.021036 \\
(0.03411)\end{array}$ \\
\hline
\end{tabular}




\begin{tabular}{|c|c|c|c|c|}
\hline & {$[-0.20481]$} & [ 0.64061] & {$[-0.25817]$} & [-0.61679] \\
\hline $\mathrm{D}(\mathrm{REER}(-3))$ & $\begin{array}{r}-1.793277 \\
(0.58305) \\
{[-3.07567]}\end{array}$ & $\begin{array}{r}-0.316929 \\
(0.10863) \\
{[-2.91758]}\end{array}$ & $\begin{array}{r}-0.024853 \\
(0.16697) \\
{[-0.14885]}\end{array}$ & $\begin{array}{r}0.017792 \\
(0.03271) \\
{[0.54389]}\end{array}$ \\
\hline $\mathrm{D}(\operatorname{REER}(-4))$ & $\begin{array}{r}-1.666844 \\
(0.57712) \\
{[-2.88819]}\end{array}$ & $\begin{array}{r}-0.062623 \\
(0.10752) \\
{[-0.58241]}\end{array}$ & $\begin{array}{r}-0.204257 \\
(0.16527) \\
{[-1.23590]}\end{array}$ & $\begin{array}{r}-0.038142 \\
(0.03238) \\
{[-1.17794]}\end{array}$ \\
\hline $\mathrm{D}(\mathrm{REER}(-5))$ & $\begin{array}{r}-0.307576 \\
(0.61286) \\
{[-0.50187]}\end{array}$ & $\begin{array}{r}-0.067774 \\
(0.11418) \\
{[-0.59357]}\end{array}$ & $\begin{array}{r}-0.102940 \\
(0.17550) \\
{[-0.58654]}\end{array}$ & $\begin{array}{r}-0.015425 \\
(0.03438) \\
{[-0.44859]}\end{array}$ \\
\hline $\mathrm{D}(\operatorname{REER}(-6))$ & $\begin{array}{r}-0.704157 \\
(0.58506) \\
{[-1.20357]}\end{array}$ & $\begin{array}{r}-0.131329 \\
(0.10900) \\
{[-1.20485]}\end{array}$ & $\begin{array}{r}-0.163119 \\
(0.16754) \\
{[-0.97361]}\end{array}$ & $\begin{array}{r}0.046358 \\
(0.03282) \\
{[1.41229]}\end{array}$ \\
\hline $\mathrm{D}(\operatorname{REER}(-7))$ & $\begin{array}{r}-0.998218 \\
(0.56483) \\
{[-1.76729]}\end{array}$ & $\begin{array}{r}0.138128 \\
(0.10523) \\
{[1.31260]}\end{array}$ & $\begin{array}{r}-0.250545 \\
(0.16175) \\
{[-1.54898]}\end{array}$ & $\begin{array}{r}-0.023994 \\
(0.03169) \\
{[-0.75714]}\end{array}$ \\
\hline $\mathrm{D}(\mathrm{REER}(-8))$ & $\begin{array}{r}-0.285117 \\
(0.54656) \\
{[-0.52166]}\end{array}$ & $\begin{array}{r}0.104395 \\
(0.10183) \\
{[1.02521]}\end{array}$ & $\begin{array}{r}0.011825 \\
(0.15652) \\
{[0.07555]}\end{array}$ & $\begin{array}{r}0.010428 \\
(0.03066) \\
{[0.34006]}\end{array}$ \\
\hline $\mathrm{D}(\mathrm{IUK}(-1))$ & $\begin{array}{r}-0.791552 \\
(0.41483) \\
{[-1.90813]}\end{array}$ & $\begin{array}{r}-0.160835 \\
(0.07729) \\
{[-2.08103]}\end{array}$ & $\begin{array}{r}0.113949 \\
(0.11879) \\
{[0.95922]}\end{array}$ & $\begin{array}{r}-0.005495 \\
(0.02327) \\
{[-0.23608]}\end{array}$ \\
\hline $\mathrm{D}(\mathrm{IUK}(-2))$ & $\begin{array}{r}-1.423427 \\
(0.40393) \\
{[-3.52392]}\end{array}$ & $\begin{array}{r}-0.092328 \\
(0.07526) \\
{[-1.22686]}\end{array}$ & $\begin{array}{r}-0.206619 \\
(0.11567) \\
{[-1.78624]}\end{array}$ & $\begin{array}{r}-0.019291 \\
(0.02266) \\
{[-0.85123]}\end{array}$ \\
\hline $\mathrm{D}(\mathrm{IUK}(-3))$ & $\begin{array}{r}-1.808437 \\
(0.40656) \\
{[-4.44815]}\end{array}$ & $\begin{array}{r}-0.062653 \\
(0.07575) \\
{[-0.82715]}\end{array}$ & $\begin{array}{r}0.225359 \\
(0.11643) \\
{[1.93566]}\end{array}$ & $\begin{array}{r}-0.003453 \\
(0.02281) \\
{[-0.15140]}\end{array}$ \\
\hline $\mathrm{D}(\mathrm{IUK}(-4))$ & $\begin{array}{r}-1.109545 \\
(0.41810) \\
{[-2.65377]}\end{array}$ & $\begin{array}{r}-0.099137 \\
(0.07790) \\
{[-1.27269]}\end{array}$ & $\begin{array}{r}0.087209 \\
(0.11973) \\
{[0.72838]}\end{array}$ & $\begin{array}{r}-0.052195 \\
(0.02346) \\
{[-2.22508]}\end{array}$ \\
\hline $\mathrm{D}(\mathrm{IUK}(-5))$ & $\begin{array}{r}-1.386932 \\
(0.44275) \\
{[-3.13254]}\end{array}$ & $\begin{array}{r}-0.096258 \\
(0.08249) \\
{[-1.16694]}\end{array}$ & $\begin{array}{r}-0.143831 \\
(0.12679) \\
{[-1.13442]}\end{array}$ & $\begin{array}{r}0.037895 \\
(0.02484) \\
{[1.52553]}\end{array}$ \\
\hline $\mathrm{D}(\mathrm{IUK}(-6))$ & $\begin{array}{r}-0.817250 \\
(0.43525) \\
{[-1.87766]}\end{array}$ & $\begin{array}{r}-0.023815 \\
(0.08109) \\
{[-0.29368]}\end{array}$ & $\begin{array}{r}0.049320 \\
(0.12464) \\
{[0.39569]}\end{array}$ & $\begin{array}{r}0.019712 \\
(0.02442) \\
{[0.80722]}\end{array}$ \\
\hline
\end{tabular}


D(IUK(-7))

$-1.228514 \quad-0.039478$

0.137572

0.028173

(0.40992)

(0.11739)

(0.02300)

[-2.99696]

$(0.07637)$

[ 1.17195]

[ 1.22497]

D(IUK(-8))

0.322109

0.059762

0.136656

0.005671

$(0.36483)$

(0.06797)

(0.10448)

(0.02047)

[0.88290]

[ 0.87923]

[ 1.30801]

[ 0.27706]

D(INFSK(-1))

$-0.181710$

$-0.155505$

$-0.178661$

$-0.039235$

(1.95968)

(0.36510)

(0.56119)

$(0.10995)$

[-0.09272]

[-0.42592]

[-0.31836]

[-0.35685]

D(INFSK(-2))

$-5.839522$

$-0.415420$

$-0.117562$

0.100932

(1.89307)

(0.35269)

(0.54211)

(0.10621)

[-3.08469]

[-1.17785]

[-0.21686]

[ 0.95030]

D(INFSK(-3))

$-8.276669$

$-0.073745$

0.366212

$-0.059723$

(1.92773)

(0.35915)

(0.55204)

(0.10816)

[-4.29348]

[-0.20533]

[ 0.66338]

[-0.55219]

D(INFSK(-4))

$-0.495376$

$-0.228961$

0.760177

$-0.021317$

(1.93824)

$(0.36111)$

(0.55505)

(0.10875)

[-0.25558]

[-0.63405]

[ 1.36957]

[-0.19603]

D(INFSK(-5))

$-2.831861$

$-0.435768$

0.290123

$-0.071924$

(1.78470)

(0.33250)

(0.51108)

(0.10013)

[-1.58675]

[-1.31057]

[ 0.56767]

[-0.71830]

D(INFSK(-6))

$-3.557653$

0.664321

$-0.386052$

$-0.140615$

(1.83775)

(0.34239)

$(0.52627)$

(0.10311)

[-1.93587]

[ 1.94026]

[-0.73356]

[-1.36377]

D(INFSK(-7))

$-2.638011$

0.546629

$-0.444821$

0.028719

(1.90880)

(0.35562)

(0.54662)

[-1.38202]

[ 1.53710]

[-0.81377]

(0.10709)

[ 0.26817]

D(INFSK(-8))

$-2.090686$

$-0.374279$

0.995910

0.234615

(1.79998)

(0.33535)

(0.51545)

(0.10099)

[-1.16151]

[-1.11609]

[ 1.93210]

[ 2.32318]

\begin{tabular}{lrrrr}
\multicolumn{1}{c}{$C$} & $\begin{array}{r}-0.128150 \\
(0.46861)\end{array}$ & $\begin{array}{r}-0.099445 \\
(0.08731)\end{array}$ & $\begin{array}{r}-0.022734 \\
(0.13419)\end{array}$ & $\begin{array}{r}-0.042857 \\
{[-0.02629)}\end{array}$ \\
& {$[-0.27347]$} & {$[-1.13906]$} & {$[-1.694009]$} & {$[-1.63009$} \\
\hline \hline R-squared & 0.556883 & 0.404923 & 0.530993 & 0.517146 \\
Adj. R-squared & 0.390714 & 0.181769 & 0.355116 & 0.336075 \\
Sum sq. resids & 2019.363 & 70.09301 & 165.5994 & 6.356580 \\
S.E. equation & 4.790335 & 0.892475 & 1.371791 & 0.268764 \\
& & & & 263
\end{tabular}




\begin{tabular}{lrrrr} 
F-statistic & 3.351302 & 1.814547 & 3.019109 & 2.856047 \\
Log likelihood & -344.3080 & -139.3044 & -191.7491 & 7.115861 \\
Akaike AIC & 6.201770 & 2.841056 & 3.700805 & 0.440724 \\
Schwarz SC & 6.983219 & 3.622505 & 4.482253 & 1.222172 \\
Mean dependent & 0.340409 & -0.082933 & 0.008686 & -0.021311 \\
S.D. dependent & 6.136985 & 0.986639 & 1.708233 & 0.329846 \\
\hline \hline
\end{tabular}

